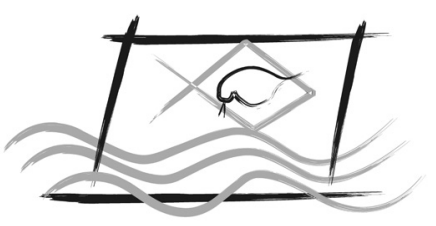

ECOTOX - BRASIL

\title{
Application of root growth endpoint in toxicity tests with lettuce
}

\section{(Lactuca sativa)}

\author{
Campagna-Fernandes, A.F. ${ }^{*} ;$ Marin, E.B. ${ }^{2} \&$ Penha, T.H.F.L. ${ }^{2}$ \\ ${ }^{1}$ Universidade Federal Rural do Semi-Árido (UFERSA), Departamento de Ciências Animais, Centro de Pesquisa em Aquicultura e Pesca \\ Sustentável do Semiárido (CEPAS), Laboratório de Ecotoxicologia Aquática do Semiárido (LABETOX); \\ ${ }^{2}$ APLYSIA Assessoria e Consultoria Ltda.
}

(Received November 19, 2014; Accept May 02, 2016)

\begin{abstract}
Ecotoxicological tests are an important tool to assess the toxicity of chemical substances and even the deleterious effects of adverse environmental conditions to different species. Ecotoxicological studies with land plants and animals are relatively recent compared to those with aquatic species, with few studies reported focusing on terrestrial species. The aim of the present study was to evaluate the sensitivity of root growth (Total Part; Radicle, Hypocotyl) in lettuce (Lactuca sativa) to sodium chloride $(\mathrm{NaCl})$, by means of exposing the seeds to concentrations of $0,1.0,2.0,4.0,8.0$ and $16.0 \mathrm{~g} \mathrm{~L}^{-1}$ for five days in Petri dishes. The average effective concentration $\left(\mathrm{EC}_{50} ; 120 \mathrm{~h}\right)$ on germination was $5.73 \pm 0.56 \mathrm{~g} \mathrm{~L}^{-1}\left(\mathrm{CI}=4.61\right.$ to $\left.6.86 \mathrm{~g} \mathrm{~L}^{-1}\right)$. The effects on root growth were detected starting at a concentration of $1.0 \mathrm{~g} \mathrm{~L}^{-1}$ of $\mathrm{NaCl}$ and the radicle (Rad) was the most sensitive and reliable structure. Root growth was a more sensitive endpoint than germination, since the effects were detected at concentrations some 10 times lower. Besides this, the use of the radicle as an endpoint, proposed in the present study, should be intensified in ecotoxicological studies, since it provides satisfactory results at low cost and in a relatively short time frame.
\end{abstract}

Keywords: germination, Lactuca sativa, root growth, sodium chloride, terrestrial ecotoxicology.

\section{INTRODUCTION}

Ecotoxicological tests are an important tool to asses the toxic potential of chemical substances and even the deleterious effects of adverse environmental conditions $(\mathrm{pH}$, temperature, oxygen) to different species. They give support to the establishment of threshold levels for commercial products and diagnosis of environmental quality, and as a consequence support decisions on management and reclamation of contaminated areas. Ecotoxicological studies with land plants and animals are relatively recent compared to those with aquatic species, so that the number of terrestrial species tested is still very low.

Lettuce (Lactuca sativa) has been widely used since it presents fast and homogeneous germination. However, most reported works have only examined germination to assess toxicity (Rivetta et al., 1997), not considering the length of the root and aerial part. The inclusion of these variables is very important, particularly of root growth since the roots are in direct contact with the soil, absorbing water and distributing it to the rest of the plant (Muhammad et al., 2006). Besides this, observations of sublethal effects (root growth) generally occur at very low concentrations of a substance in relation to the lethal effect, permitting the establishment of toxic concentrations that are really safe for the test organism. In this respect, the use of the root growth variable of $L$. sativa in the present study is justifiable, especially considering that this species' seeds germinate quickly and the roots grow linearly (McCormac et al., 1990), facilitating obtaining and analyzing the results.

Some works have considered lethal and sublethal effects (Hund-Rinke \& Simon, 2005; Muhammad et al., 2006; Radic et al., 2007; Okçu et al., 2005; Jamil \& Rha, 2007), but all of these have used the entire root. The present study evaluated the section of the root that is most sensitive to $\mathrm{NaCl}$. This substance was chosen because it has been widely employed

*Corresponding author: Aline F. Campagna-Fernandes e-mail: campagna@ufersa.edu.br 
as a reference in ecotoxicological tests with various aquatic and terrestrial species, such as: Chironomus xanthus, Daphnia magna, Hydra attenuata, Pseudokirchneriella subcapitata, Vibrio fischeri, Medicago sativa, Oryza sativa, Zea mays, Beta vulgaris and Gossypium hirsutum (Santos et al., 2007; Umbuzeiro \& Hachich, 2009; Azhdari et al., 2010). Besides this, high salt content in the soil or irrigation water is one of the most important stress factors in arid and semi-arid regions, lowering agricultural yields (Abogadallah et al., 2010). The determination of the most sensitive endpoints to assess environmental quality enables the optimization of ecotoxicological studies, where choosing the variable that best responds to the contaminant means reduced time and costs to obtain reliable results.

Therefore, the aim of the present study was to establish the sensitivity range of $L$. sativa to $\mathrm{NaCl}$, considering germination, and to assess the toxic effects of this substance on the root growth, with focus on the most sensitive section of the root.

\section{MATERIALS AND METHODS}

The bioassays involved the exposure of 160 lettuce seeds in Petri dishes, distributed in four replications. The control was composed of distilled water and the treatments consisted of exposure to five concentrations of sodium chloride $(\mathrm{NaCl})$ $\left(1.0,2.0,4.0,8.0\right.$ and $\left.16.0 \mathrm{~g} \mathrm{~L}^{-1}\right)$. The acute bioassay lasted five days (120 hours). At the end we noted the percentage of germinated seeds, considering them to be only those showing root growth of at least $20 \mathrm{~mm}$. The EC50;120h values were calculated with the statistical method Trimmed SpearmanKarber (Hamilton et al. 1977).

We measured the root lengths of the germinated seeds with a ruler and pachymeter, considering three different root sections: the hypocotyl $(\mathrm{Hpc})$; radicle ( $\mathrm{Rad})$ and total part $(\mathrm{TP}=\mathrm{Hpc}+\mathrm{Rad})$, to verify the most sensitive metric to assess toxicity. For the statistical analysis, we used the nonparametric Kruskal-Wallis test, followed by the Dunn test when necessary to compare the measures found in the root sections exposed to the different $\mathrm{NaCl}$ concentrations and the control. The results were considered significant when $p<0.05$. The lethal evaluations (germination) and sublethal ones (root growth) followed the recommendations of the USEPA (1996). All told seven sensitivity bioassays were carried out.

\section{RESULTS}

Table 1 show the results obtained in the seven sensitivity tests, considering the germination endpoint. As can be seen, the standard deviation for the EC50;120h values was very low $(0.56)$ resulting in a very satisfactory coefficient of variation (below 10\%). The average EC50;120h was $5.73 \mathrm{~g} \mathrm{~L}^{-1}$ and the confidence interval was $4.61 \mathrm{~g} \mathrm{~L}^{-1}$ to $6.86 \mathrm{~g} \mathrm{~L}^{-1}$ of NaCl. Figure 1 shows the control card prepared for these bioassas.

Root growth evaluations showed a pattern in the responses of the individuals submitted to the five treatments (Table 2;
Table 1 - Results of the bioassays with $L$. sativa in Petri dishes, using $\mathrm{NaCl}$ as the reference substance. SD: standard deviation; CI: confidence interval; $\mathrm{CV}$ : coefficient of variation.

\begin{tabular}{|c|c|c|c|}
\hline Bioassay & $\begin{array}{l}\text { Starting date } \\
\text { (month/day) }\end{array}$ & $\begin{array}{c}\mathrm{EC}_{50} ; 120 \mathrm{~h} \\
\left(\mathrm{~g} \mathrm{~L} \mathrm{~L}^{-1}\right)\end{array}$ & $\begin{array}{c}\text { CI } 95 \% \\
\left(\mathrm{~g} \mathrm{~L}^{-1}\right) \\
\end{array}$ \\
\hline 1 & $\mathrm{Mar} / 30$ & 5.28 & $(4.86-5.72)$ \\
\hline 2 & Apr/28 & 5.27 & $(4.97-5.60)$ \\
\hline 3 & $\mathrm{Jul} / 29$ & 5.87 & $(5.57-6.19)$ \\
\hline 4 & Aug/10 & 5.65 & $(5.36-5.96)$ \\
\hline 5 & Aug/11 & 6.91 & $(6.41-7.45)$ \\
\hline 6 & Aug/24 & 5.53 & $(5.07-6.03)$ \\
\hline 7 & Aug/30 & 5.60 & $(5.15-6.09)$ \\
\hline Average $\mathrm{EC}_{50} ; 120 \mathrm{~h}$ & & \multicolumn{2}{|c|}{$5.73 \mathrm{~g} \mathrm{~L}^{-1}$} \\
\hline SD & & \multicolumn{2}{|c|}{0.5623} \\
\hline CI & & \multicolumn{2}{|c|}{$4.61-6.86 \mathrm{~g} \mathrm{~L}^{-1}$} \\
\hline CV & & \multicolumn{2}{|c|}{$9.81 \%$} \\
\hline
\end{tabular}

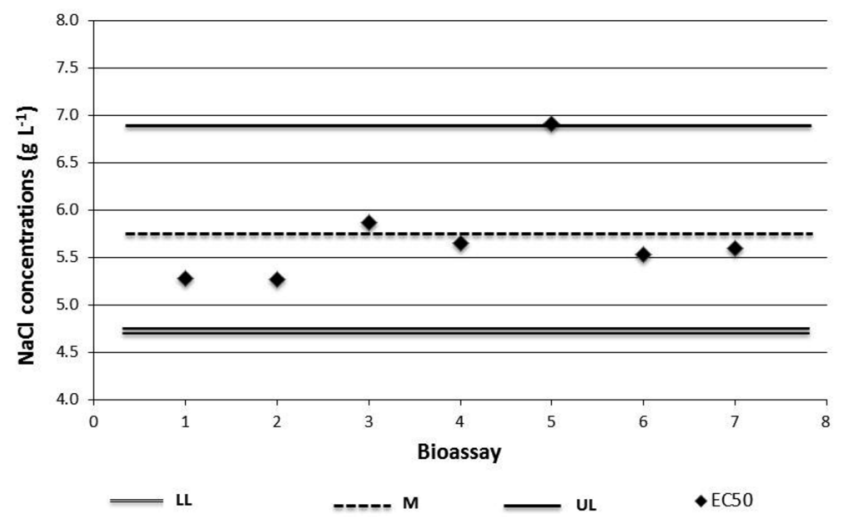

M: mean; LL: lower limit; UL: upper limit.

Figure 1: Control card of the bioassays with L. sativa seeds exposed to different $\mathrm{NaCl}$ concentrations in Petri dishes.

Fig. 2). Considering all the bioassays (B), the seeds exposed in the control group presented a smaller hypocotyl (Hpc) of the primary root than the radicle ( $\mathrm{Rad})$, with mean values ranging from $1.514 \pm 0.59$ to $2.676 \pm 0.66$ and $2.788 \pm 1.31$ to $3.680 \pm 1.19$, respectively.

In the treatments with $\mathrm{NaCl}$, the root growth pattern was different, with lower Rad than Hpc (1.206 \pm 0.37 to 1.866 \pm 0.40 and $0.696 \pm 0.27$ to $1.083 \pm 0.32$, respectively) and minimum values at the concentration of $8.0 \mathrm{~g} \mathrm{~L}^{-1}$. For the $\mathrm{Hpc}$, it was also possible note stimulating effects in relation to the control group. The differences found between all the treatments with $\mathrm{NaCl}$ and the control were significant, but the measurement of the Rad was the most sensitive endpoint, since the values were significantly lower than in the control (negative effect) starting at a concentration of $1.0 \mathrm{~g} \mathrm{~L}^{-1} \mathrm{of}$ $\mathrm{NaCl}$ in all bioassays, while the values for the Hpc were significantly lower only for the seeds exposed to the $\mathrm{NaCl}$ concentration of $8.0 \mathrm{~g} \mathrm{~L}^{-1}$. There was no germination at the highest concentration $\left(16.0 \mathrm{~g} \mathrm{~L}^{-1}\right)$, so it was not possible to asses the initial root growth. 
Table 2: Means and standard deviations of the root length (TP, Hpc and Rad) of L. sativa exposed to different NaCl concentrations and result of the KruskalWallis test. TP: Total part of root; Hpc: hypocotyl; Rad: radicle; B: bioassay. *significant in relation to the control ( $<<0.05)$. The $16 \mathrm{~g} \mathrm{~L}^{-1}$ concentration was not analyzed because there was no germination.

\begin{tabular}{|c|c|c|c|c|c|c|}
\hline Bioassay & $\begin{array}{l}\text { Root } \\
\text { Section } \\
\text { (cm) }\end{array}$ & Control & $\begin{array}{c}1.0 \\
g L^{-1}\end{array}$ & $\begin{array}{l}2.0 \\
g L^{-1}\end{array}$ & $\begin{array}{l}4.0 \\
\mathrm{~g} \mathrm{~L}^{-1}\end{array}$ & $\begin{array}{c}8.0 \\
\mathrm{~g} \mathrm{~L}^{-1}\end{array}$ \\
\hline \multirow{3}{*}{ B1 } & $\mathrm{TP}$ & $4.302 \pm 1.84$ & $4.853 \pm 1.46$ & $4.340 \pm 0.59$ & $3.318 \pm 0.68^{*}$ & $1.860 \pm 0.50^{*}$ \\
\hline & Нpc & $1.514 \pm 0.59$ & $2.610 \pm 0.57^{*}$ & $2.545 \pm 0.27 *$ & $2.300 \pm 0.46^{*}$ & $1.206 \pm 0.37$ \\
\hline & $\operatorname{Rad}$ & $2.788 \pm 1.31$ & $2.322 \pm 0.71$ & $1.929 \pm 0.51^{*}$ & $1.270 \pm 0.45^{*}$ & $0.696 \pm 0.27^{*}$ \\
\hline \multirow{3}{*}{ B2 } & $\mathrm{TP}$ & $5.751 \pm 0.47$ & $5.636 \pm 1.12$ & $5.078 \pm 1.06^{*}$ & $3.845 \pm 0.73 *$ & $2.300 \pm 0.2^{*}$ \\
\hline & $\mathrm{Hpc}$ & $2.335 \pm 1.15$ & $2.966 \pm 0.66^{*}$ & $2.912 \pm 0.60^{*}$ & $2.625 \pm 0.59 *$ & $1.450 \pm 0.31$ \\
\hline & $\operatorname{Rad}$ & $3.415 \pm 0.87$ & $2.670 \pm 0.74 *$ & $2.166 \pm 0.73 *$ & $1.220 \pm 0.43 *$ & $0.850 \pm 0.12 *$ \\
\hline \multirow{3}{*}{ B3 } & $\mathrm{TP}$ & $6.123 \pm 1.47$ & $5.549 \pm 0.94 *$ & $5.133 \pm 0.79 *$ & $4.324 \pm 0.65^{*}$ & $2.645 \pm 0.44 *$ \\
\hline & $\mathrm{Hpc}$ & $2.676 \pm 0.66$ & $3.388 \pm 0.59^{*}$ & $3.356 \pm 0.69 *$ & $3.126 \pm 0.51^{*}$ & $1.840 \pm 0.35^{*}$ \\
\hline & $\operatorname{Rad}$ & $3.446 \pm 0.91$ & $2.160 \pm 0.49^{*}$ & $1.776 \pm 0.43^{*}$ & $1.198 \pm 0.32 *$ & $0.804 \pm 0.18^{*}$ \\
\hline \multirow{3}{*}{ B4 } & $\mathrm{TP}$ & $6.201 \pm 1.75$ & $6.120 \pm 1.04$ & $6.136 \pm 1.30$ & $4.750 \pm 0.78 *$ & $2.525 \pm 0.35^{*}$ \\
\hline & Hpc & $2.521 \pm 0.70$ & $3.097 \pm 0.57^{*}$ & $3.359 \pm 0.80^{*}$ & $3.221 \pm 0.47^{*}$ & $1.708 \pm 0.36$ \\
\hline & $\mathrm{Rad}$ & $3.680 \pm 1.19$ & $3.023 \pm 0.67^{*}$ & $2.777 \pm 0.77^{*}$ & $1.528 \pm 0.45^{*}$ & $0.816 \pm 0.21^{*}$ \\
\hline \multirow{3}{*}{ B5 } & $\mathrm{TP}$ & $5.680 \pm 1.77$ & $5.728 \pm 1.45$ & $5.497 \pm 0.94$ & $4.444 \pm 0.73 *$ & $2.950 \pm 0.50^{*}$ \\
\hline & Hрc & $2.326 \pm 0.89$ & $3.132 \pm 1.05^{*}$ & $3.406 \pm 0.55^{*}$ & $3.246 \pm 0.70^{*}$ & $1.866 \pm 0.40^{*}$ \\
\hline & $\operatorname{Rad}$ & $3.354 \pm 1.06$ & $2.595 \pm 0.74 *$ & $2.090 \pm 0.68^{*}$ & $1.198 \pm 0.39^{*}$ & $1.083 \pm 0.32 *$ \\
\hline
\end{tabular}

For the entire primary root (TP), it was also possible to note negative effects values in relation to the control group, starting at a concentration of $1.0 \mathrm{~g} \mathrm{~L}^{-1}$ of $\mathrm{NaCl}$. Although a similar sensitivity related to Rad (observed effect from $1 \mathrm{~g} \mathrm{~L}^{-1}$ of $\mathrm{NaCl}$ ) the results found in different bioassays with TP were highly variable, indicating that the endpoint did not exhibit good repeatability for the evaluation of sensitivity to $\mathrm{NaCl}$. The opposite was observed for Rad, whose observed effect concentration in all bioassays was in $1 \mathrm{~g} \mathrm{~L}^{-1}$. The mean root growth values of the seeds in the control group varied between $4.302 \pm 1.84$ and $6.201 \pm 1,75$, while for the treatments with $1.0,2.0,4.0,8.0$ and $16.0 \mathrm{~g} \mathrm{~L}^{-1}$ of $\mathrm{NaCl}$, these figures were $4.853 \pm 1.46$ to $6.120 \pm 1.04,4.340 \pm 0.59$ to $6.136 \pm 1.30$, $3.318 \pm 0.68$ to $4.750 \pm 0.78,1.860 \pm 0.50$ to $2.950 \pm 0.50$ and 0.000 , respectively. Despite the significant effects observed for the root growth, there was a decreasing sensitivity scale to $\mathrm{NaCl}$ in the following order: $\mathrm{Rad} \sim \mathrm{TP}>\mathrm{Hpc}$, since the concentrations that caused significant effects were 1.0, 1.0 and $8.0 \mathrm{~g} \mathrm{~L}^{-1}$, respectively. The Rad was 8 times more sensitive than the Hpc.

\section{DISCUSSION}

The two most important environmental factors responsible for reducing plant productivity in the world are salinity and drought (Serrano et al., 1999). Salinity in the soil and irrigation water is a problem mainly in arid and semi-arid regions, and can severely limit crop yields or even make it impossible to grow certain plants (Shannon, 1998). However, despite extensive studies, there is still a good deal of controversy over plants' salt tolerance mechanisms (Neumann, 1995).
The results found in the present work corroborate those reported in other studies that have found a deleterious effect on the germination potential of seeds exposed to salt. Radic et al. (2007) analyzed the effects of $\mathrm{NaCl}$ on the germination and root growth of genetic variations of corn kernels exposed for seven days in Petri dishes to similar $\mathrm{NaCl}$ concentrations to those used in this study $\left(1.2,4.1,7.0,9.9,11.7\right.$ and $12.8 \mathrm{~g} \mathrm{~L}^{-1}$ of $\left.\mathrm{NaCl}\right)$. The germination was significantly affected starting at $11.7 \mathrm{~g}$ $\mathrm{L}^{-1}$ of $\mathrm{NaCl}$, and that root growth diminished with increasing concentrations. The EC50 concentration found was around two times that of the average established in the present study.

Muhammad et al. (2006), assessing the effects of $\mathrm{NaCl}$ on the germination of the seeds of beet (Beta vulgaris), cabbage (Brassica oleracea capitata L.), purple amaranth (Amaranthus paniculatus) and pak-choi (Brassica compestris), found that increasing salt concentrations caused a reduction in germination, but the effects were not significant in relation to the control for beet and cabbage seeds at concentrations starting at $4.7 \mathrm{dS} \mathrm{m}^{-1}$. Besides this, the authors found negative effects on the growth of the shoots and roots, in the last case similar to our results here.

Shonjani (2002) studied the effects of $\mathrm{NaCl}(0,2.92,5.85$ and $\left.11.7 \mathrm{~g} \mathrm{~L}^{-1}\right)$ on the germination and growth of the seeds of rice (Oryza sativa), corn (Zea mays), beet (Beta vulgaris) and cotton (Gossypium hirsutum) and found increasing delays in root emergence for all the species and a reduction in germination with progressively higher salt concentrations. The author also found that the germination of beet and cotton was strongly inhibited starting at a concentration of $5.85 \mathrm{~g} \mathrm{~L}^{-1}$ of NaCl , while the growth reduction of the aerial part was most severely affected at a concentration of $11.7 \mathrm{~g}$ 
B1

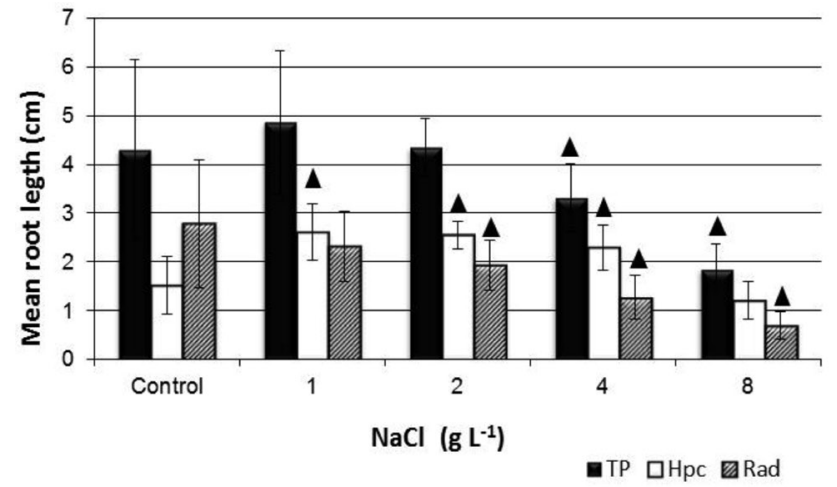

B3

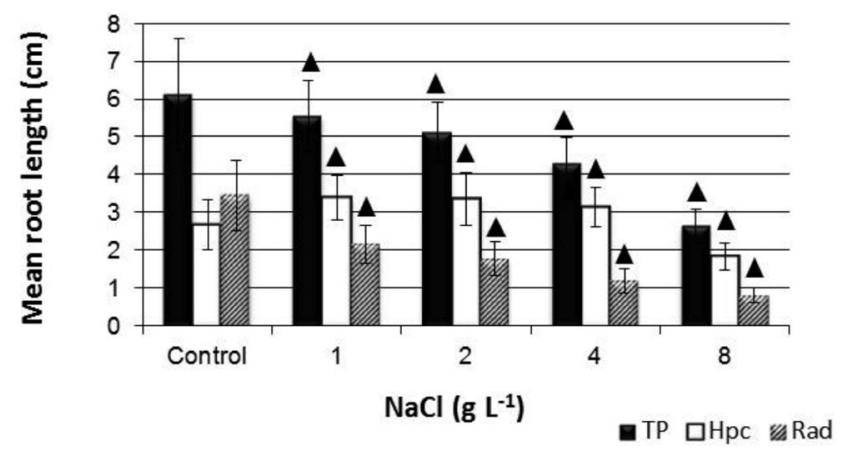

B2

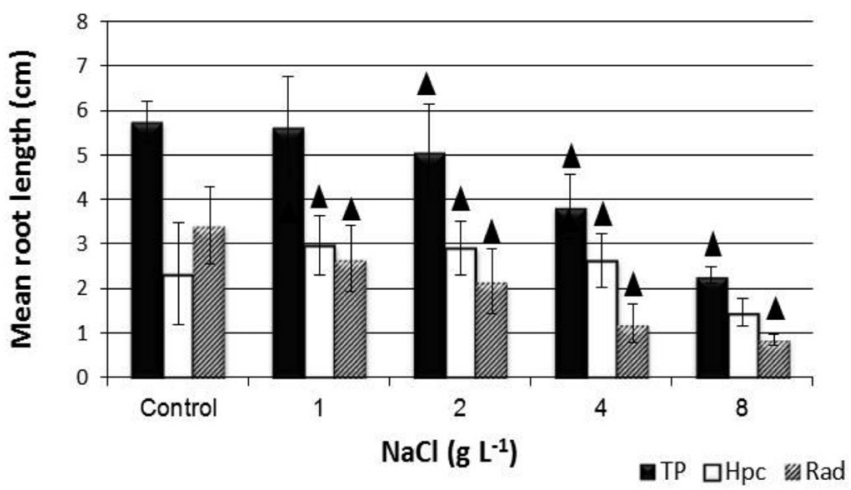

B4

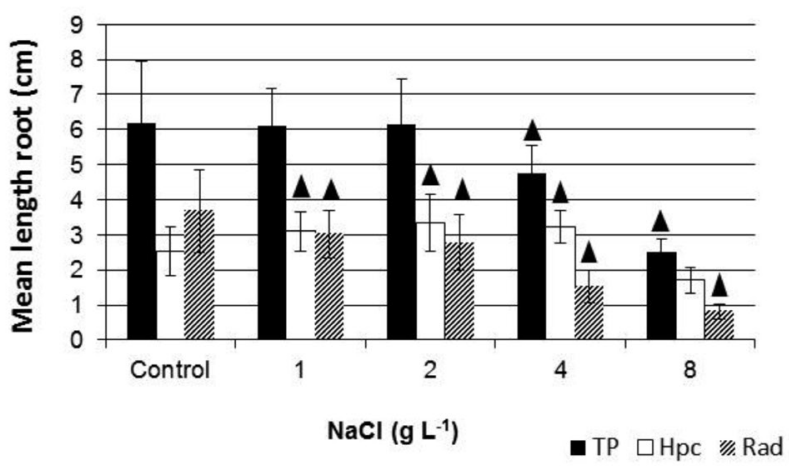

B5

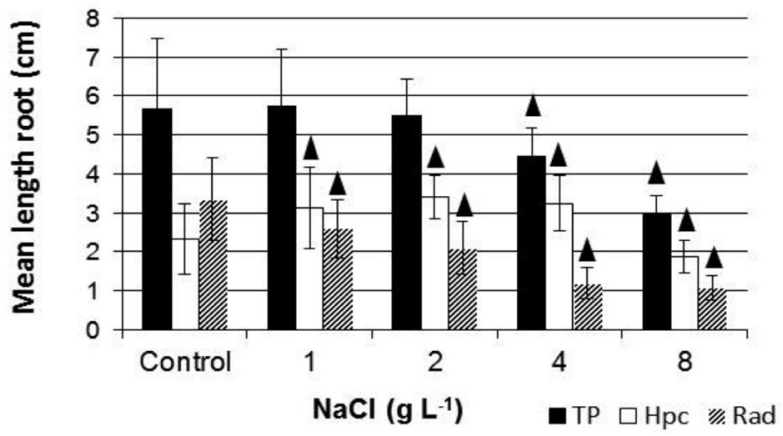

Figure 2: Mean root length of germinated $L$. sativa seeds exposed to different concentrations of $\mathrm{NaCl}$. The symbol $(\mathbf{\Delta})$ indicates significant difference in relation to the control ( $\mathrm{p}<0.05$; Kruskal-Wallis test); TP: Total part of root; Hpc: hypocotyl; Rad: radicle; $\perp=$ standard deviation; $\mathbf{B}=$ Bioassay.

$\mathrm{L}^{-1}$. He found the same response pattern for all four species tested, with only the sensitivity of each species varying. The inhibition concentration detected $\left(5.85 \mathrm{~g} \mathrm{~L}^{-1}\right)$ was near the mean $\mathrm{EC}_{50} ; 120 \mathrm{~h}$ established in the present study $\left(5.73 \mathrm{~g} \mathrm{~L}^{-1}\right)$, but significant effects on the growth of $L$. sativa were detected starting at a concentration of $1.0 \mathrm{~g} \mathrm{~L}^{-1}$ of $\mathrm{NaCl}$, lower than one-tenth the concentration in the study by Shonjani (2002).

The differences in sensitivity of various species exposed to $\mathrm{NaCl}$, comparing the results of this study with the works cited above, can be explained by the different salt tolerance capacities of each species, and even of individual plants. Plants react differently to salinity, with some cultivars able to tolerate relatively high concentrations while others are extremely sensitive. Furthermore, this tolerance varies not only due to the salt concentration, but also in function of management practices, climate and the nature and relative proportions of ions in the soil (Richards, 1969). Therefore, the differences found among the studies can reflect the different sensitivities of each species, but also can be due to the methodology used.

The results established a mean EC50;120h of $5.73 \mathrm{~g} \mathrm{~L}^{-1}$ of $\mathrm{NaCL}$ considering germination, although there were significant effects on root growth detected starting at a concentration of $1.0 \mathrm{~g} \mathrm{~L}^{-1}$, with the Rad being the most sensitive and reliable endpoint for analysis in ecotoxicological tests. The present study evaluated what portion of the root is most sensitive for ecotoxicological studies. This observation will enable optimization of future tests, since the use of the most sensitive endpoint will reduce the time and cost of testing programs. 
Furthermore, there are no standards established in Brazil for conducting seed germination tests in dishes, so the present study can contribute to the establishment of these standards and orient future studies.

Some basic factors that can interfere in the germination and root growth of lettuce seeds are water and oxygen, and some of the most complex are light, temperature and endogenous inhibitors (Nascimento, 2002). When seeds are placed in water to start germination, rapid uptake of water into the tissue occurs, along with large and rapid leakage of solutes, such as ions, amino acids, sugars and organic acids (Shonjani, 2002). Therefore, germination occurs in four different stages: 1) imbibation: uptake of water, largely by the protein components of the seed; 2) hydration and activation of informational mechanisms: nucleic acids and enzymes; 3 ) cell enlargement and division; and 4) emergence of the root and shoot through the coat (Berlyn, 1972).

Considering the physiological processes involved in germination and root growth, Leopold and Willing (1984) proposed that the toxic effects of salt occur by inducing lesions in cell membranes, resulting in the leakage of the cell content. Besides this, ions can alter the volume of the cell and its nucleus and inhibit or stimulate the formation of nucleic acids and protein synthesis.

The main toxic effects of salt stress, mainly of $\mathrm{NaCl}$, result from at least three factors: osmotic stress, specific toxicity of ions and inducement of nutrient deficiency (Kingsbury \& Epstein, 1986). With respect to osmotic potential, when the concentrations of salts in the soil increase, the water potential decreases, the turgor potential declines and the cells finally stop growing. Under these water stress conditions, the stomata generally close, inhibiting photosynthesis and stunting plant growth (Shonjani, 2002). However, the degree of suppression varies according to the species and even biotype. Therefore, reduced growth can be the result of the effects of ionic relations, the state of the water, physiological or biochemical processes or a combination of those factors (Greenway \& Munns, 1980).

Other studies assessing the germination and growth of seeds in Petri dishes have found similar results as those here. Nunes et al. (2009), evaluating the toxicity of $\mathrm{KCl}, \mathrm{NaCl}$ and $\mathrm{CaCl}_{2}$ on the germination and growth of Crotalaria juncea, found that the increased concentration of those salts, expressed by the reduction of the osmotic potential, impaired germination and initial growth. Besides this, the authors concluded that the deleterious effects on osmotic potential were more severe in the following order, respectively: $\mathrm{KCl}, \mathrm{CaCl}_{2}$ and $\mathrm{NaCl}$ on germination; $\mathrm{KCl}, \mathrm{NaCl}$ and $\mathrm{CaCl}_{2}$ on initial growth; and $\mathrm{NaCl}, \mathrm{KCl}$ and $\mathrm{CaCl}_{2}$ on phytotoxicity.

Botelho \& Perez (2001), in a similar study to that of Nunes et al. (2009), found the same results for horsebush (Peltophorum dubium), where the negative effects of reduced osmotic potential increased with higher concentrations of salts.

Another study assessing the toxic potential of salinity was that of Younis et al. (2010), in which the authors exposed Vicia $f a b a$ to serial concentrations of $\mathrm{NaCl}(2.5,5.0,7.48,10.0,12.5$ and $15.0 \mathrm{~g} \mathrm{~L}^{-1}$ ) and found increasingly negative effects on germination and root growth with rising salt concentrations. The germination was reduced by $50 \%$ when the seeds were exposed to the concentration of $10.0 \mathrm{~g} \mathrm{~L}^{-1}$ and the root growth gradually declined with increasing salt levels.

The results found in the present study on the sensitivity of the different root structures to $\mathrm{NaCl}$ show a trend for reduced TP and augmented Hpc with increasing salt concentrations in relation to the control. According to Shonjani (2002), one of plants' detoxification mechanisms when faced with a toxic substance is to reduce the shoot-root ratio, to improve the water balance by maintaining the potential for water absorption and reducing transpiration. Thus, the results of the present study suggest that when faced with salt stress, $L$. sativa reduces the Rad-Hpc ratio, in a growth strategy to reduce absorption of the toxic component (since the Rad is more branched, and thus has greater absorption potential) and increase nutritional reserves in the Hpc (more robust).

The results presented allow concluding that $L$. sativa is a relevant bioindicator of environmental stress and can be used more widely in ecotoxicological tests. The bioassays in Petri dishes were satisfactory to assess the toxic effects of $\mathrm{NaCl}$ on L. sativa, since there were declining germination and growth in response to increasing salt concentrations. Therefore, both the methodology employed and the reference substance should be considered in environmental studies. The root growth was more sensitive than germination to assess the toxicity of $\mathrm{NaCl}$, since the effects were detected at a concentration some ten times lower. For root growth, there was decreasing sensitivity to $\mathrm{NaCl}$ in the order $\mathrm{Rad} \sim \mathrm{TP}>\mathrm{Hpc}$. Although similar sensitivity between TP and Rad, the results for the $\mathrm{Rad}$ had greater repeatability, and therefore more reliable in ecotoxicological studies. Therefore, to reduce the time and expense of ecotoxicological studies while still assuring reliable results, the germination and Rad length endpoints of L. sativa should be considered in complementary form.

\section{ACKNOWLEDGMENTS}

This work was supported by grants from FAPES (Fundação de Amparo à Pesquisa do Espírito Santo) and $\mathrm{CNPq}$ (Conselho Nacional de Desenvolvimento Científico e Tecnológico).

\section{REFERENCES}

ABOGADALLAH, G.M., SERAG, M.M., EL-KATOUNY, T.M. \& QUICK, W.P. 2010. Salt tolerance at germination and vegetative growth involves different mechanisms in barnyard grass (Echinochloa crusgalli L.) mutants. Plant Growth Regul, 60:112. http://dx.doi.org/10.1007/s10725-009-9413-9

AYAZ, F.A., KADIOGLU,A. \& TURGUT, R. 2000. Water stress effects on the content of low molecular weight carbohydrates and phenolic acids in Ctenanthe setosa (Rose) Eichler. Can. J. Plant Sci., 80: 373-378. http://dx.doi.org/pubs.aic.ca/doi/pdf/10.4141/ P99-005

AZHDARI, G.H., TAVILI, A. \& ZARE, M.A. 2010. Effects of various salts on the germination of two cultivars of Medicago 
sativa. Front. Agric. China, 4(1): 63-68. http://dx.doi. org/10.1007/s11703-009-0078-y

BERLYN, G.P. 1972. Seed germination and morphogenesis. In: Kozlowski, T.T. (ed), Seed Biology, Importance, Development and Germination. New York, Academic Press, pp. 223-312.

BOTELHO, B.A. \& PEREZ, S.C.J.G.A. 2001. Estresse hídrico e reguladores de crescimento na germinação de sementes de canafístula. Scientia Agricola, Piracicaba. 58: 43-49.

EPSTEIN, E. 1972. Mineral Nutrition of Plants: Principles and Perspectives. John Wiley and Sons, New York, 176p.

GREENWAY, H. \& MUNNS, R. 1980. Mechanism of salt resistance in non-halophytes. Annu. Rev. Plant Physiol., 3: 149-190. http:// dx.doi.org/10.1146/annurev.pp.31.060180.001053

HAMILTON, M.A., RUSSO, R.C. \& THURSTON, R.U. 1977. Trimmed Spearman-Karber method for estimating median lethal concentrations in toxicity bioassays. Environm Sci Technol., 11(7): 714-719. http://dx.doi.org/10.1021/es60130a004.

HUND-RINKE, K. \& SIMON, M. 2005. Terrestrial ecotoxicity of eight chemicals in a systematic approach. J Soils Sediments 5(1): 59-65. http://dx.doi.org/10.1065/jss2004.10.123.

JAMIL, M. \& RHAE, E.S. 2007. Gibberellic Acid $\left(\mathrm{GA}_{3}\right)$ enhances seed water uptake, germination and early seedling growth in sugar beet under salt stress. Pakistan Journal of Biological Sciences., 10 (4): 654-658. http://dx.doi.org/10.3923/pjbs.2007.654.65.

KINGSBURY, R.W., EPSTEIN, E., 1986. Salt sensitivity in wheat: a case for specific ion toxicity. Plant Physiol., 80: 651-654. http://dx.doi.org/10.1104/pp.80.3.651.

LIMA, K.L., CAVALCANTE, L.F. \& FEITOSA FILHO, J.C. 2001. Efeitos de fontes e níveis de salinidade da água de irrigação sobre a germinação e o crescimento da pinheira. Engenharia Agrícola, 21: 135-144.

LEOPOLD, A.C. \& WILLING, R.P. 1984. Evidence for toxicity effects of salt on membranes. In: Staples, R.C., Toenniessen, C.H. (eds.), Salinity Resistance in Plants. Strategies for Crop Improvement. John Wiley and Sons, New York, pp. 67-76.

MAAS, E.V. \& NIEMAN, R.H. 1978. Physiology of plant tolerance to salinity. In: ASA, CSSA, SSA, Crop Tolerance and suboptimal land conditions. American Society of Agronomy, USA, pp.277-299. http://dx.doi.org/10.2134/asaspecpub32.c13.

METIVIER, J. \& PAULILO, M.T. 1980. The utilization of cotyledonary reserves in Phaseolus vulgaris L. cv. Carioca. I. Changes in total amylolytic and proteolytic activity and the effect of 6-benzyladenine and gibberellic acid upon whole seedlings. J. Exp. Bot., 131: 1257-1270. http://dx.doi.org/10.1093/ $\mathrm{jxb} / 31.5 .1257$.

McCORMAC, A.C., KEEFE, P.D. \& DRAPER, S.R. 1990. Automated vigor testing of field vegetables using image analysis. Seed Science Technology, 18: 103-112.

MUHAMMAD, J., DEOG, B.L., KWANG, Y.J., MUHAMMAD, A., SHEONG, C.L. \& EUI, S.R. 2006. Effect of salt $(\mathrm{NaCl})$ stress on germination and early seedling growth of four vegetables species. Journal Central European Agriculture, 7: 273-282. http://dx.doi.org/10.1007/s11056-011-9265-9.

NASCIMENTO, W.M. 2002. Germinação de sementes de alface. Circular Técnica da EMBRAPA, Ministério da Agricultura, Pecuária e Abastecimento. ISSN 1415-3033.

NEUMANN, P.M. 1995. Inhibition of root growth by salinity stress: Toxicity or an adaptive biophysical response. In: Baluska, F., Ciamporova, M., Gasparikova, O., Barlow, P.W. (eds.), Structure and Function of Roots, Kluwer Academic Publishers,
The Netherlands, pp. 299-304. http://dx.doi.org/10.1007/978-94017-3101-0 39.

NUNES, A.S., LOURENÇÃO, A.L.F., PEZARICO, C.R., SCALON, S.P.Q. \& GONÇALVES, M.C. 2009. Fontes e níveis de salinidade na germinação de sementes de Crotalaria juncea L. Ciênc. Agrotec., Lavras, 33: 753-757. http://dx.doi.org/10.1590/ S1413-70542009000300013.

OKÇU, G., KAYA, M.D. \& ATAK, M. 2005. Effects of salt and drought stresses on germination and seedling growth of pea (Pisum sativum L.). Turk J Agric For., 29: 237-242.

RADIĆ, V., BEATOVIĆ, D. \& MRDA, J. 2007. Salt tolerance of corn genotypes (Zea mays L.) during germination and later growth. Journal of Agricultural Sciences, 52: 115-120. http:// dx.doi.org/10.2298/JAS0702115R.

RICHARDS, L.A. 1969. Diagnosis and improvement of saline and alkali soils. Washington D.C., U.S, 166p.

RIVETTA, A., NEGRINI, N. \& COCUCCI, M. 1997. Involvement of $\mathrm{Ca}^{+2}$-calmodulin in $\mathrm{Cd}^{+2}$ toxicity during the early phases of radish (Raphanus sativus L.) seed germination. Plant Cell and Environment, 20: 600-608. http://dx.doi.org/10.1111/j.13653040.1997.00072.x.

SANTOS, M.A.P.F., VICENSOTTI, J. \& MONTEIRO, R.T.R. 2007. Sensitivity of four test organisms (Chironomus xanthus, Daphnia magna, Hydra attenuata and Pseudokirchneriella subcapitata) to $\mathrm{NaCl}$ : an alternative reference toxicant. Journal of the Brazilian Society of Ecotoxicology, 2: 229-236. http:// dx.doi.org/10.5132/jbse.2007.03.004

SERRANO, R., MACIA, F.C. \& MORENO, V. 1999. Genetic engineering of salt and drought tolerance with yeast regulatory genes. Sci. Hortic., 78: 261-269. http://dx.doi.org/10.1016/ S0304-4238(98)00196-4.

SHANNON, M.C.1998. Adaptation of plant to salinity. Adv. Agron., 60: 75-119.

SHONJANI, S. 2002. Salt Sensitivity of rice, maize, sugar beet, and cotton during germination and early vegetative growth. Dissertation, University of Giessen, 139p.

UMBUZEIRO, G.A., HACHICH, E.M., MAGRI, E.V., TAKEDA, S.H.K. \& SATO, M.I.Z. 2010. Influência da sacarose e do cloreto de sódio na avaliação da toxicidade de amostras ambientais para Vibrio fischeri. J. Braz. Soc. Ecotoxicol., 5: 71-73. http://dx.doi. org/10.5132/jbse.2010.01.002

UNITED ENVIRONMENT PROTECTION AGENCY (EPA), 712-C-96-154. OPTPS850.4200. 1996. Ecological effects test guidelines. Seed germination/ Root elongation toxicity test. Public Draft, USA.

WELBAUM, G.E., TISSAOUI, T. \& BRADFORD, K.J. 1990. Water relations of seed development and germination in muskmelon (Cucumis melo L.). III. Sensitivity of germination to water potential and abscisic acid during development. Plant Physiol., 92: 1029-1037. http://dx.doi.org/10.1104/pp.92.4.1029

WERNER, J.E. \& FINKELSTEIN, R.R. 1995. Arabidopsis mutants with reduced response to $\mathrm{NaCl}$ and osmotic stress. Physiol. Plant., 93: 659-666. http://dx.doi.org/10.1111/j.1399-3054.1995. tb05114.x

YOUNIS, M.E., HASANEEN, M.N.A. \& KAZAMEL, A.M.S. 2010. Exogenously applied ascorbic acid ameliorates detrimental effects of $\mathrm{NaCl}$ and mannitol stress in Vicia faba seedlings. Protoplasma, 239: 39-48. http://dx.doi.org/10.1007/s00709-0090080-5. 